\title{
Dampak Pembinaan Karang Taruna Dengan Model Transformative Learning Terhadap Keberdayaan Pemuda Di Karang Taruna Hasta Jaya Kabupaten Jember
}

\author{
Hikmah Syifa'ani, A.T. Hendra Wijaya, Lutfi Ariefianto \\ Pendidikan Luar Sekolah, Universitas Jember. Jl. Kalimantan No. 37, Tegal Boto, Jember 62811, \\ Indonesia \\ Email: syifahikmah212@yahoo.com; lutfipls.fkip@unej.ac.id
}

\begin{abstract}
Abstrak
Pembinaan karang taruna dengan model transformative learning dilakukan karena masih ditemukannya karang taruna yang berada pada kondisi fakum dan kurangnya partisipasi pemuda yang berdampak terhadap keberdayaan pemuda. Sehingga menyebabkan karang taruna on/off. Pada penelitian ini, rumusan masalah yaitu bagaimana dampak pembinaan karang taruna dengan model Transformative Learning terhadap keberdayaan pemuda di Karang Taruna Hasta Jaya Kelurahan Jember Lor Kecamatan Patrang Kabupaten Jember. Jenis penelitian yang digunakan adalah penelitian deskriptif dengan jenis data kualitatif. Teknik perolehan data dilakukan dengan observasi, wawancara dan dokumentasi. Analisis data dilakukan menggunakan analisis merumuskan masalah, sebelum di lapangan, serta analisis Model Miles dan Huberman yaitu reduksi data, penyajian data, dan verifikasi data. Hasil penelitian ini menunjukkan bahwa dampak pembinaan karang taruna dengan model transformative learning mencakup dampak instruksional dan dampak pengiring terjadi pada pemuda Karang Taruna Hasta Jaya dimana dampak tersebut memberikan perubahan dan peningkatan terhadap keberdayaan pemuda yang meliputi potensi dan peran aktif pemuda.
\end{abstract}

Kata Kunci: Pembinaan karang taruna, transformative learning, keberdayaan pemuda

\section{The Impact Of Karang Taruna Development With Transformative Learning Model On Youth Empowerment In Karang Taruna Hasta Jaya Jember}

\begin{abstract}
Karang Taruna development with transformative learning guidance is carried out because there are still young cadets who are in poor condition and lack of youth participation which has an impact on youth empowerment. So that causes cadets on / off. The purpose of writing this article is to describe the impact of karang taruna development with transformative learning model on youth empowerment in Karang Taruna Hasta Jaya, Jember Lor, Patrang, Jember. This research uses descriptive research with a qualitative approach. Data acquisition techniques are carried out by the method of observation, interviews and documentation. While data analysis was performed using analysis of problem formulation, prior analysis in the field, and analysis of Miles and Huberman models, namely data reduction, data presentation, and data verification. The results of this study indicate that the impact of youth training with the transformative learning model includes instructional impacts and accompaniment impacts that occurred in Karang Taruna Hasta Jaya where the impact provided a change and an increase in youth empowerment which included the potential and active role of youth.
\end{abstract}

Keywords: Development of youth organizations, transformative learning, youth empowerment 


\section{Learning Community: Jurnal Pendidikan Luar Sekolah, 3 (2), September 2019 - 18}

Hikmah Syifa'ani

\section{PENDAHULUAN}

Karang taruna sebagai wadah
generasi muda berfungsi untuk
mengembangkan potensi anggotanya berdasarkan program kerja yang telah ditetapkan. Sehingga, karang taruna tersebut mampu berkembang dan aktif dengan beberapa kegiatan yang dimiliki.

Pada kenyataannya, masih ada karang taruna yang mengalami kondisi fakum. Kondisi ini didukung dengan studi pendahuluan yang ada pada penelitian sebelumnya tahun 2014 bahwa karang taruna mengalami beberapa fase perkembangan yang masuk dalam empat kategori yaitu fase rintisan, fase keemasan, fase kefakuman, dan fase kebangkitan kembali (Hasan, 2017: 180). Salah satu organisasi yang mengalami keadaan seperti ini yaitu Karang Taruna Hasta Jaya yang berada di daerah Kelurahan Jember Lor Kecamatan Patrang Kabupaten Jember.

Karang Taruna Hasta Jaya mengalami pasang surut organisasi. Program kerja juga masih belum terlaksana secara maksimal dan kurangnya partisipasi pemuda sehingga menyebabkan karang taruna on/off. Selain itu juga, masih ada pemuda yang kurang berpartisipasi pada kegiatan di karang taruna sebagai organisasi sosial kemasyarakatan. Berdasarkan data hasil Susenas (Survei Sosial Ekonomi Nasional) Tahun 2015, presentase pemuda yang mengikuti kegiatan sosial kemasyarakatan di sekitar tempat tinggalnya selama tiga bulan terakhir mengalami pasang surut yaitu 82,73\% menurun menjadi 81,19\% dan beranjak naik $81,97 \%$. Situasi seperti ini bisa menghambat keaktifan karang taruna sebagai organisasi sosial kemasyarakatan.

Menindaklanjuti adanya kejadian seperti diatas, maka diadakan Pembinaan Karang Taruna dengan model transformative learning. Pembinaan dalam model ini diharapkan mampu memberikan dampak berupa perubahan dan peningkatan potensi dan peran aktif pemua. Pembinaan ini dalam bentuk Pelatihan Motivasi dan Manajerial. Pelatihan ini adalah salah satu program pengabdian masyarakat oleh salah satu dosen di Universitas Jember.

Pelatihan motivasi dan manajerial diisi dengan beberapa materi yaitu Peran Karang Taruna dalam Pemberdayaan Masyarakat dan Manajerial Organisasi Karang Taruna. Pelatihan ini dilakukan dengan pemberian motivasi, materi dan praktek berkaitan dengan program kerja karang taruna. Pelatihan ini bertujuan untuk meningkatkan motivasi dan kemampuan dalam berorganisasi dengan baik. Motivasi ini nantinya berguna bagi anggota karang taruna yaitu pemuda agar lebih termotivasi untuk berorganisasi dengan menyumbangkan pemikaran terkait manajemen organisasi dengan membuat program kerja karang taruna.

Berdasarkan studi pendahuluan yang peneliti lakukan, sebanyak $82 \%$ dari 11 anggota Karang Taruna Hasta Jaya yang mengikuti pelatihan mengatakan bahwa pelatihan tersebut memberikan manfaat bagi dirinya. Manfaat yang muncul yaitu perubahan dan peningkatan pada keberdayaan pemuda yang mampu memberikan perbaikan bagi Karang Taruna Hasta Jaya agar lebih baik lagi untuk kedepannya. Berdasarkan pemaparan latar belakang di atas, maka peneliti tertarik untuk mengadakan penelitian mengenai "Dampak Pembinaan Karang Taruna dengan Model Transformative Learning terhadap Keberdayaan Pemuda di Karang Taruna Hasta Jaya Kelurahan Jember Lor Kabupaten Jember".

\section{METODE}

Penelitian ini merupakan jenis penelitian deskriptif dengan jenis data kualitatif. Sementara itu, metode yang digunakan adalah studi kasus. Penelitian ini dilakukan selama 6 bulan yaitu dimulai dari bulan September 2018 sampai Maret 2019 di Karang Taruna Hasta Jaya bertempat di RT 001/ RW 011 Kelurahan Jember Lor Kecamatan Patrang Kabupaten Jember sebagai tempat yang dipilih untuk penelitian menggunakan teknik purposive area. Teknik yang digunakan dalam penentuan informan yaitu snowball sampling. Informan kunci yaitu pemuda Karang Taruna Hasta Jaya yang mengikuti pembinaan karang taruna dengan model transformative learning. Informan pendukung yaitu pengurus dan anggota Karang Taruna Hasta Jaya.

Teknik pengumpulan data yang digunakan yaitu wawancara, observasi, dan dokumentasi. Peneliti melakukan wawancara 


\section{Learning Community: Jurnal Pendidikan Luar Sekolah, 3 (2), September 2019 - 19 Hikmah Syifa'ani}

pada informan yaitu pemuda Karang Taruna Hasta Jaya yang nantinya akan dilihat kesesuaiannya dengan hasil observasi atas tindakan pemuda. Sementara itu, proses analisis dilakukan dari merumuskan masalah, sebelum masuk ke lapangan, serta reduksi data, penyajian data, dan verifikasi data.

\section{HASIL DAN PEMBAHASAN}

Berdasarkan data yang diperoleh saat penggalian dan pengumpulan informasi dilapangan, dapat dirumuskan hasil penelitian yang sesuai dengan rumusan masalah untuk menjawab bagaimana dampak pembinaan karang taruna dengan model transformative learning terhadap keberdayaan pemuda di Karang Taruna Hasta Jaya Kelurahan Jember Lor Kecamatan Patrang Kabupaten Jember bahwa terjadi dampak pembinaan karang taruna dengan model transformative learning terhadap keberdayaan pemuda. Dampak ini terjadi berupa dampak instruksional dan dampak pengiring. Dampak instruksional terdiri atas lahirnya sebuah pemikiran baru terkait karang taruna dan kesadaran untuk menyikapi permasalahan karang taruna. Pemikiran baru ini terlihat dari peserta pembinaan jadi lebih tahu tentang arti penting organisasi dan munculnya inovasiinovasi baru. Kesadaran pemuda dalam menyikapi permasalahan karang taruna juga telah muncul. Pemuda Karang Taruna Hasta Jaya dalam menyikapi permasalahan dilakukan dengan musyawarah yaitu melalui rapat bulanan yang merupakan kebijakan dari karang taruna.

Sementara itu, untuk dampak pengiring terdiri atas peningkatan pengetahuan tentang karang tarunadimana mereka mengerti bahwa karang taruna adalah suatu organisasi yang berperan dalam kepemudaan seperti melatih kepemimpinan dan kerjasama dan pengetahuan tentang alternatif pemecahan masalah yang dapat diterapkan yaitu adanya penyelesaian masalah yang dilakukan secara bertahap yaitu dari identifikasi masalah, musyawarah, dan solusi permasalahan.

Kedua dampak ini memberikan perubahan dan peningkatan terkait potensi dan peran aktif pemuda yaitu potensi ini meliputi potensi kepemimpinan, kewirausahaan, dan kepeloporan. Sementara itu untuk peran aktif meliputi peran aktif sebagai kekuatan moral, kontrol sosial, dan agen perubahan. Perubahan dan peningkatan potensi dan peran aktif pemuda ini terjadi karena adanya pemikiran baru yang muncul, kesadaran pemuda, serta pengetahuan tentang karang taruna dan alternatif pemecahan masalah yang dapat diterapkan.

Perubahan potensi pemuda ditandai dengan adanya peningkatan pengetahuan pemuda bahwa pemuda dilatih potensi kepemimpinannya dalam karang taruna yaitu dengan berani bertanggung jawab atas tugasnya sebagai ketua. Pemuda lebih aktif dalam berpendapat terkait potensi kepeloporan, dan pemikiran baru yang ada pada diri pemuda yang berbeda dengan acuan pemikiran yang sebelumnya serta kesadaran pemuda untuk menyikapi permasalahan membuat pemuda memiliki inovasi baru terkait program kerja yaitu kewirausahaan dengan berjualan kalender.

Peningkatan peran aktif pemuda sebagai kekuatan moral yaitu pemuda menjadi lebih sopan dan mampu berbaur dengan masyarakat. Peningkatan peran aktif pemuda sebagai kontrol sosial terlihat dari komunikasi yang dibangun dengan masyarakat menjadi lebih baik karena adanya pemikiran baru terkait peran serta karang taruna di masyarakat. Peningkatan peran aktif pemuda sebagai agen perubahan dimulai dari adanya peningkatan pengetahuan terkait karang taruna yang mampu membuat pemuda saling bekerjasama sehingga nantinya mampu membawa perubahan peran aktif yang lebih baik pada dirinya, organisasi, dan masyarakat.

Berdasarkan hasil dari penelitian yang telah dilakukan peneliti menggunakan pengumpulan data melalui teknik wawancara dan observasi akan dianalisis sebagai berikut : Dampak pembinaan karang taruna dengan model transformative learning terhadap keberdayaan pemuda telah terjadi pada pemuda Karang Taruna Hasta Jaya. Dampak ini terdiri atas dampak instruksional dan dampak pengiring. Dampak instruksional yaitu munculnya pemikiran baru terkait karang taruna yaitu pemuda Karang Taruna Hasta Jaya mampu mengerti tentang pentingnya karang taruna, munculnya inovasi baru, serta memahami akan peran serta 
karang taruna di masyarakat. Hal ini sesuai dengan pemikiran yang lebih baik yaitu dengan memiliki suatu jiwa inovasi baru terkait suatu hal dan menciptakan sesuatu yang bermanfaat bagi pemuda itu sendiri (Sugiono dkk, 2015: 7). Ketika inovasi telah muncul, acuan berpikiran pemuda akan lebih baik bahwa di karang taruna tidak hanya sekedar tahu, tetapi mampu memberikan sesuatu yang baru.

Selain itu juga, muncul kesadaran pemuda untuk menyikapi permasalahan karang taruna. Hal ini ditandai oleh adanya kegiatan musyawarah melalui rapat bulanan karang taruna. Mereka berdiskusi dengan adanya permasalahan tersebut dan segera mencari jalan keluarnya agar permasalahan dapat terselesaikan. Hal ini sesuai dengan yang dikatakan oleh Zeman (2001) dalam Hastjarjo (2005: 81) bahwa salah satu arti pokok kesadaran yaitu sebagai pikiran (mind). Kesadaran digambarkan sebagai keadaan mental yang berisikan keinginan. Dimana Keinginan pemuda untuk menyikapi permasalahan ini dimulai dari proses yang ada pada pikiran mereka kemudian muncul suatu keinginan yaitu melakukan diskusi permasalahan yang dihadapi karang taruna.

Sementara itu, juga terjadi dampak pengiring yang terdiri atas peningkatan pengetahuan tentang karang taruna dan alternatif permasalahan yang dapat diterapkan. Peningkatan pengetahuan tentang karang taruna ditandai dengan pemuda Karang Taruna Hasta Jaya menjadi mengerti akan organisasi yang diikuti. Pemuda belajar untuk berorganisasi dengan baik dan benar dengan mengasah kemampuan yang dimiliki. Pemuda yang telah mampu berkembang dalam organisasi, diharapkan nantinya mampu membawa karang taruna dalam masyarakat dengan baik. Hal ini sesuai dengan pemuda yang memiliki pengetahuan tentang karang taruna mampu menjalankan peranan karang taruna secara maksimal (Handayani dkk, 2015:2). Pemuda dengan pengetahuan yang dimiliki mampu menjalankan organisasi dengan baik sehingga mampu memberikan dampak yang baik pula.

Sementara itu, peningkatan pengetahuan tentang alternatif pemecahan masalah yang dapat diterapkan ini ditandai dengan penyelesaian permasalahan secara bertahap yaitu diawali dengan identifikasi masalah, musyawarah melalui rapat dengan beberapa masukan yang ada dari anggota. Hal ini sesuai dengan yang dikatakan oleh Febriyanti dan Irawan (2017) dalam Yokhebed (2018:78), bahwa pemecahan masalah adalah strategi untuk mewujudkan harapan dengan cara yang sesuai. Tahapan yang dilalui pemuda karang taruna untuk menemukan alternatif pemecahan masalah ini dilakukan agar permasalahan terselesaikan.

Dampak instruksional dan dampak pengiring ini memberikan perubahan dan peningkatan terkait potensi dan peran aktif pemuda. Perubahan potensi yang dimiliki oleh pemuda karang taruna terdiri atas potensi kepemimpinan, kewirausahaan, dan kepeloporan. Perubahan potensi kepemimpinan ini terjadi karena adanya peningkatan pengetahuan tentang karang taruna. Hal ini terlihat dari pemuda karang taruna yang lebih bertanggung jawab atas struktural organisasi yang telah ditetapkan. Khususnya pemimpin di Karang Taruna Hasta Jaya yang lebih bisa mengarahkan organisasi agar lebih berkembang. Pemimpin lebih bisa mengatur struktural organisasi sesuai dengan kebutuhan. Hal ini sesuai yang disampaikan oleh Daswati (2012: 784), pemimpin memiliki tanggung jawab besar dalam mencapai tujuan organisasi dan berperan sebagai penggerak bagi sumber daya lainnya agar mereka mampu berkoordinasi dengan lancar. Pemimpin harus mampu melihat anggota-anggotanya serta menjalin komunikasi dengan baik.

Potensi lain yang mengalami perubahan yaitu potensi kewirausahaan. Perubahan potensi ini terjadi karena lahirnya pemikiran baru yang ada pada diri pemuda yang berbeda dengan acuan pemikiran yang sebelumnya yaitu dengan munculnya hasil Karang Taruna Hasta Jaya yang merupakan produk pertama kewirausahaan yaitu pembuatan kalender tahun 2019. Pembuatan kalender ini merupakan suatu wujud kreatifitas yang disalurkan pemuda melalui gambar-gambar desain grafis yang dituangkan dalam bentuk kalender. Hal ini sesuai dengan yang disampaikan bahwa wirausaha memiliki ciri-ciri yaitu dinamis, kreatif, inovatif, dan berani mengambil resiko (Schermerhorn dalam Rumijati, 2010: 190). 


\section{Learning Community: Jurnal Pendidikan Luar Sekolah, 3 (2), September 2019 - 21 Hikmah Syifa'ani}

Pembuatan produk ini bertujuan untuk menambah uang kas karang taruna agar lebih meningkat. Selain itu, juga melatih pemuda untuk berani berbicara dengan masyarakat sekitar melalui promosi kalender.

Selain potensi diatas, potensi kepeloporan pemuda Karang Taruna Hasta Jaya juga berubah. Hal ini ditandai dengan keberanian pemuda dalam menyampaikan ide-idenya pada saat rapat. Hasil yang didapat juga memuaskan. Pemuda yang sebelumnya pasif, menjadi aktif. Ide-ide yang mereka berikan tertuang dalam program kerja yang lebih tertata dan teratur dari sebelumnya.

Sementara itu, peningkatan peran aktif oleh pemuda karang taruna terdiri atas peran aktif sebagai kekuatan moral, kontrol sosial, dan agen perubahan. Peningkatan peran aktif pemuda sebagai kekuatan moral ditandai dengan pemuda menjadi lebih sopan dalam bertingkah laku baik. Ketika pemuda telah sopan, maka akan mudah untuk berhubungan dengan masyarakat. Hal ini sesuai yang disampaikan oleh Sinulingga (2016: 224), adanya panutan nilai, moral, dan norma dalam diri manusia dan kehidupan akan sangat menentukan totalitas diri individu atau jati diri manusia, lingkungan sosial, dan kehidupan individu. Pemuda berbuat baik dimulai dari dirinya sendiri, keluarga, masyarakat sekitar. Untuk mencapai pada peningkatan kekuatan moral, Karang Taruna Hasta Jaya mempunyai program kerja yaitu pengajian. Melalui pengajian ini diharapkan pemuda mampu memegang teguh agama dan mempunyai moral yang baik untu diterapkan dalam kehidupannya.

Peningkatan peran aktif pemuda sebagai kontrol sosial terlihat dari komunikasi yang dibangun dengan masyarakat menjadi lebih baik. Hal ini terjadi karena lahir pemikiran baru terkait peran serta karang taruna di masyarakat Pemuda didalam organisasi yaitu Karang Taruna Hasta Jayaberlatih untuk memiliki kontrol diri, dimana di karang taruna akan memberikan manfaat mampu melatih diri untuk berani menyampaikan pendapat sehingga akan membentuk kepribadian pemuda. Hal ini sesuai yang disampaikan bahwa sikap mempertahankan yaitu memiliki kontrol, merupakan cara yang tepat untuk mencapai tujuan yang diinginkan dan memaksimalkan fungsi organisasi sehingga tercapai kegiatan dengan menyesuaikan norma yang berlaku (Reiss dalam Alias, dkk, 2013: 2). Pemuda juga tidak lupa berkonsultasi dengan pihak RT atas kegiatankegiatan yang ada sehingga segala tindakan pemuda mampu diterima dengan baik oleh masyarakat.

Peningkatan peran aktif pemuda sebagai agen perubahan dimulai dari peningkatan pengetahuan terkait karang taruna sehingga pemuda mampu untuk saling bekerjasama. Ketika pemuda sudah seperti itu, maka rasa kebersamaan itu muncul. Pemuda dengan rasa kebersamaanya mampu membawa organisasi lebih kompak dan mampu membawa perubahan. Hal ini sesuai dengan yang disampaikan oleh Havelock dalam Amalia, dkk (2017: 1572), mengungkapkan agen perubahan ini membantu terlaksananya suatu perubahan. Pemuda dengan perubahan yang dimiliki mampu membawa perubahan untuk organisasi dan masyarakat sekitar.

\section{SIMPULAN}

Berdasarkan analisis data maka dapat disimpulkan bahwa pembinaan karang taruna dengan model transformative learning berdampak positif terhadap keberdayaan pemuda di Karang Taruna Hasta Jaya. Dampak positif ini berkaitan dengan dampak instruksional dan dampak pengiring yang terjadi setelah mengikuti pembinaan dengan model transformative learning. Dampak tersebut memberikan perubahan dan peningkatan terhadap keberdayaan pemuda. Keberdayaan ini meliputi potensi dan peran aktif pemuda. Perubahan dan peningkatan potensi dan peran aktif pemuda ini terjadi karena adanya pemikiran baru yang muncul yang berbeda dari acuan sebelumnya tentang karang taruna, kesadaran pemuda untuk menyikapi permasalahan, serta pengetahuan terkait karang taruna dan alternatif pemecahan masalah yang dapat diterapkan. Perubahan dan peningkatan ini terkait potensi dan peran aktif pemuda dalam organisasi karang taruna. 


\section{Learning Community: Jurnal Pendidikan Luar Sekolah, 3 (2), September 2019 - 22}

Hikmah Syifa'ani

\section{DAFTAR PUSTAKA}

Alias, M, Fatmawati, dan Mochtaria. (2013). Kontrol Sosial Tokoh Masyarakat (Ustad) dalam Mengatasi Penyimpangan Perilaku Remaja di Desa Limbung Kecamatan Sungai Raya Kabupaten Kubu Raya. Jurnal Tesis PMIS-UNTAN-PSS-2013. Online(http://jurnal.untan.ac.id/inde x.php/jpmis/article/view/1166).

Diakses 31 Januari 2019

Amalia, N.F, U. Dayati, dan Z. Nasution. (2017). Peran Agen Perubahan dalam Pelaksanaan Program Pemberdayaan Masyarakat Pesisir Pantai Bajulmati Kabupaten Malang. Jurnal Pendidikan, 2(11), $\quad 1572 . . \quad$ Online (http://journal.um.ac.id/index.php/ip tpp/article/view/10249/4894).

Diakses 31 Januari 2019

Daswati. 2012. Implementasi Peran Kepemimpinan dengan Gaya Kepemimpinan Menuju Kesuksesan Organisasi. Jurnal Academica, 04(01), 784.

Online(http://jurnal.untad.ac.id/jurn al/index.php/academica/article/view /2272). Diakses 01 Februari 2019

Hasan, F. (2017). Model Pembinaan Transformatif Untuk Program Pembinaan Karang Taruna. Jurnal Pancaran Pendidikan, 6(1), 180. Online

(http://pancaranpendidikan.or.id/art icle/view.php?id=306). Diakses 19 April 2018

Handayani, A. Y., N. Purnaningsih, dan M. Sarma. 2015. Persepsi Pemuda Terhadap Peranan Karang Taruna dalam Penanganan Masalah Sosial. Scientific Repository. Online (https://repository.ipb.ac.id/handle/ 123456789/70831). Diakses 27 Maret 2019Subdirektorat Statistik Pendidikan dan Kesejahteraan Sosial. 2016. Statistik Pemuda 2015. Online (https://bps.go.id/website/pdf publi kasi/Statistik-Pemuda-Indonesia2015--rev.pdf). Diakses 19 April 2018

Hastjarjo, D. 2005. Sekilas Tentang Kesadaran (Consciousness). Buletin Psikologi, 13(2), $81 \quad$. Online (https://jurnal.ugm.ac.id/buletinpsik ologi/article/view/7478). Diakses 27 Maret 2019

Rumijati, A. 2010.Pengaruh Bakat Potensi Kewirausahaan dan Metode Pembelajaran Terhadap Minat Berwirausaha Mahasiswa. Journal of Innovation in Business and Economics, 01(02), $190 . \quad$ Online (http://ejournal.umm.ac.id/index.php Ljibe/article/download/4802/pdf). Diakses 31 Januari 2019

Sinulingga, S. P. 2016. Teori Pendidikan Moral Menurut Emile Durkheim Relevansinya bagi Pendidikan Moral Anak Di Indonesia. Jurnal Filsafat 26(2), $224 . \quad$ Online (https://journal.ugm.ac.id/wisdom/a rticle/view/12784). Diakses 31 Januari 2019

Sugiono, A., E. N. Rohmah, dan Y. F. Fitriyani. 2015. Penerapan IPTEK Bagi Masyarakat Berbasis Industri Kreatif Bagi Karang Taruna di Kecamatan Galis Pamekasan. 4(1), 7. Online (http://uim.ac.id/jurnal/index.php/e konomi/article/viewFile/123/93.). Diakses 26 Maret 2019

Yokhebed, T. 2018. Peningkatan Keterampilan Pemecahan Masalah (Problem Solving) Calon Guru Biologi Melalui Pembelajaran Berbasis Kearifan Lokal. Jurnal Pendidikan Matematika dan IPA, 9(1), 78.0nline (http://jurnal.untan.ac.id/index.php/ PMP/article/view/23701). Diakses 27 Maret 2019. 